\title{
PEMBUATAN TEPUNG BIJI KETAPANG (Terminalia catappa) SEBAGAI BAHAN PENGOLAHAN ANEKA CAKE PADA KELOMPOK PKK PERMATA HIJAU BANJARBARU
}

\author{
Rina Muhayah Noor Pitri dan Kissinger \\ Fakultas Kehutanan, Universitas Lambung Mangkurat \\ E-mail: rina.muhayah@ulm.ac.id
}

\begin{abstract}
ABSTRAK
Biji Ketapang (Terminalia catappa L.) banyak terdapat di lingkungan selama ini dibiarkan berserakan menjadi sampah. Pengabdian ini bertujuan untuk memfasilitasi pembuatan tepung biji Ketapang terhadap mitra kerjasama. Indikator capaian dari tujuan kegiatan adalah paling tidak $80 \%$ anggota mitra berminat dan memahami pelaksanaan kegiatan. Paling tidak terdapat 2 orang anggota mitra yang terindikasi memiliki keterampilan membuat tepung biji Ketapang sebagai bahan pengolahan aneka cake. Mitra kegiatan PKM ini adalah kelompok PKK Permata Hijau RT.011 RW.003 Banjarbaru Kalimantan Selatan. Metode yang digunakan dalam pengabdian adalah transfer iptek dalam bentuk sosialisasi dan demonstrasi pembuatan tepung dari biji Ketapang untuk pengolahan aneka cake. Rancangan evaluasi yang dinilai adalah i) keingintahuan, keseriusan, minat; ii) daya serap dan keterampilan. Evaluasi keingintahuan, minat dan keseriusan peserta tergolong tinggi (90\%). Semua peserta hadir dan melakukan diskusi 2 arah. Peserta mengikuti pengabdian dari awal sampai acara selesai. Evaluasi daya serap pengetahuan dan keterampilan peserta juga sangat tinggi (80\%), di mana mereka memahami proses pemanfaatan biji Ketapang untuk dijadikan tepung. Terdapat 4 orang anggota PKK yang mampu menjadi fasilitator dalam membuat tepung biji Ketapang sebagai bahan pengolahan aneka cake. Keterampilan dasar dalam membuat kue menjadi faktor penguasaan keterampilan fasilitator.
\end{abstract}

Kata Kunci : biji, tepung, Ketapang, cake, PKK.

\section{PENDAHULUAN}

$\begin{array}{rlr}\text { Hevira } & \text { et al. } & \text { (2015) } \\ \text { menyebutkan } & \text { bahwa } & \text { Ketapang }\end{array}$

(Terminalia catappa) adalah tumbuhan serbaguna yang dapat dimanfaatkan akar, batang, daun dan buahnya. Bagian pohon Ketapang yang belum banyak dimanfaatkan adalah biji ketapang. Biji ketapang adalah biji yang terdapat dalam buah Ketapang. Bentuk biji buah Ketapang seperti biji bunga matahari atau kwaci tetapi agak cembung.
Biji Ketapang memiliki rasa yang gurih dan kandungan gizinya tinggi antara lain: protein $(25,3 \%)$, gula (16\%), serat $(11,75 \%)$, karbohidrat (5,8\%) (Lia et al. 2010). Biji Ketapang memiliki kadar protein dan serat yang tinggi tetapi memiliki kadar karbohidrat yang rendah.

Pembuatan makanan dari bahan dengan protein dan serat yang tinggi seperti biji Ketapang sangat baik untuk kesehatan. Pembuatan tepung biji 
Ketapang untuk bahan aneka cake merupakan inovasi terbaru untuk meningkatkan manfaat kesehatan cake yang dihasilkan karena memiliki serat dan protein tinggi dan diolah dari bahan limbah yang tidak termanfaatkan.

Kelompok Pemberdayaan dan Kesejahteraan Keluarga (PKK) Komplek Permata Hijau Banjarbaru merupakan kelompok yang anggotanya adalah warga komplek Permata Hijau Banjarbaru. Kelompok PKK ini memiliki kegiatan yang beragam yang bertujuan untuk meningkatkan pemberdayaan dan kesejahteraan keluarga. Beragam kegiatan dan keterampilan yang dikembangkan oleh anggota PKK dapat memberikan dampak positif untuk kemandirian keluarga yang menjadi anggota PKK.

Pohon Ketapang sebagai penghasil biji Ketapang banyak ditemukan disekitar perumahan warga di komplek Permata Hijau. Fenomena yang terjadi di lapangan, biji dari buah Ketapang hanya akan menjadi sampah dan dibiarkan berserakan dan tidak termanfaatkan. Daging kulit buahnya menjadi sumber pakan satwa liar seperti kelelawar dan tupai.

Seiring dengan upaya pemberdayaan anggota kelompok PKK, perlu inovasi dalam memanfaatkan sumberdaya yang terdapat di sekitar lingkungan yang dapat menjadi sumber pemasukan ekonomi bagi anggota PKK. Pemilihan biji Ketapang sebagai bahan yang bisa dibuat tepung untuk olahan aneka cake relatif potensial dikembangkan. Transfer teknologi, pendampingan dan pelatihan untuk membuat tepung biji Ketapang sebagai bahan pengolahan aneka cake akan bermanfaat bagi anggota PKK. Keterampilan tersebut dapat menambah keterampilan penganekaragaman dalam pengolahan makanan sehat untuk keluarga serta upaya dalam diversifikasi usaha.

Pengabdian ini berupaya memfasilitasi anggota PKK untuk dapat memanfaatkan biji Ketapang yang selama ini dianggap sebagai sampah menjadi bahan tepung dalam pengolahan aneka cake. Peningkatan kemampuan para anggota PKK ini dilakukan menggunakan metode fasilitasi dengan dasar teoritik dari pendekatan literatur, pengalaman tim pengabdi dan hasil diskusi yang dilakukan dengan anggota PKK. Manfaat kegiatan di antaranya adalah: i) Bagi khalayak sasaran kunci: a. Meningkatkan pengetahuan dan 
keterampilan dalam pemanfaatan sampah biji Ketapang. b. Modal pengetahuan dan ketrampilan yang akan menciptakan tenaga-tenaga terampil dalam pembuatan tepung biji Ketapang sebagai bahan subtitusi terigu dalam pengolahan aneka cake. ii) Bagi tim pengabdi: a. Meningkatkan keperdulian terhadap anggota masyarakat dalam memanfaatkan bahan-bahan alami yang selama ini tidak dimanfaatkan. $b$. Meningkatan keterampilan dalam melakukan pelatihan keahlian dengan dasar pengetahuan yang didukung oleh pengalaman praktis.

\section{METODE KEGIATAN}

\section{Lokasi, Waktu dan Khalayak} Sasaran

Lokasi pelaksanan kegiatan berada di RT 011 RW 003 Kelurahan Sungai Ulin Kecamatan Banjarbaru Utara Kota Banjarbaru. Pelaksanaan kegiatan direncanakan selama 2 bulan kegiatan. Khalayak sasaran adalah anggota Kelompok PKK Permata Hijau dengan kategori orang dewasa yang dapat membaca dan menulis, aktif menyebarkan informasi terhadap pengetahuan dan keterampilan yang diberikan sebanyak 10 orang.

\section{Kerangka Pemecahan Masalah}

Berdasarkan analisis situasi masalah permasalahan yang dihadapi kelompok PKK Permata Hijau dalam peningkatan manfaat sumberdaya alam yang terdapat di sekitar perumahan adalah sebagai berikut:

1. Mitra belum memiliki motivasi tinggi dalam mengembangkan diversifikasi produk dari sumberdaya yang ada di sekitar perumahan untuk meningkatkan pemberdayaan usaha sekaligus program peningkatan kesejahteraan anggota PKK.

2. Mitra belum memiliki pengetahuan dalam memanfaatkan bahan seperti limbah biji Ketapang. Biji Ketapang selama ini dibiarkan berserakan dan menjadi sampah yang berserakan di sekitar perumahan.

3. Pengetahuan tentang keunggulan dari aspek kesehatan biji Ketapang seperti karbohidrat yang rendah, protein dan serat yang tinggi belum dimiliki peserta.

4. Mitra belum menguasai metode pembuatan biji Ketapang menjadi tepung yang dapat digunakan dalam pembuatan aneka cake berserat tinggi yang baik dari aspek Kesehatan. 
Jalan keluar atau solusi yang ditawarkan kepada mitra terkait berbagai kelemahan yang dimiliki dalam memanfaatkan sumberdaya alam yang terdapat di sekitar perumahan bagi anggota PKK Permata Hijau adalah sebagai berikut:

1. Memberikan sosialisasi tentang pengetahuan tentang peluangpeluang usaha dengan pemanfaatan bahan-bahan disekitar, salah satunya dari pemanfaatan biji Ketapang. Hal ini penting untuk membuka wawasan berfikir tentang diversifikasi usaha yang mungkin dilakukan.

2. Memberikan pengetahuan kepada mitra tentang pemanfaatan sampah biji Ketapang yang bisa dibuat tepung sebagai bahan pengolahan aneka cake

3. Menyampaikan pengetahuan yang didukung oleh tinjauan referensi ilmiah tentang kandungan gizi biji Ketapang dan berbagai alternatif pemanfaatannya sebagai bahan pembuatan pakan sehat

4. Memberikan pengetahuan dan keterampilan dalam pembuatan tepung biji Ketapang sebagai bahan pengolahan aneka cake

\section{Metode Pelaksanaan Kegiatan}

Tahapan pelaknaan pengabdian mencakup: 1) Sosialisasi pengetahuan tentang manfaat biji Ketapang yang didukung oleh referensi ilmiah; 2) Penyampaian informasi tentang tata cara pembuatan tepung biji Ketapang; 3) Pendampingan keterampilan pembuatan tepung biji Ketapang; 4) Menyusun rencana dan metode penentuan proporsi subtitusi tepung biji Ketapang terhadap terigu dalam pembuatan aneka cake.

Adapun metode kegiatan pengabdian ini dilakukan dengan langkah berikut:

1. Penyampaian materi teoritis oleh pengabdi kepada khalayak sasaran (mitra) dengan diskusi aktif dua arah.

2. Demontrasi keterampilan yang dilakukan oleh khalayak sendiri tanpa bantuan tim pengabdi. Pengabdi hanya sebagai pengamat.

3. Pendampingan dalam menyusun rencana dan metode penentuan proporsi subtitusi tepung biji Ketapang terhadap terigu dalam pembuatan aneka cake melalui diskusi aktif dua arah yang didukung oleh referensi ilmiah. 
4. Evaluasi keberlanjutan kegiatan pada tenggang waktu 2 bulan setelah kegiatan pengabdian dilaksanakan.

\section{Rancangan Evaluasi}

Evaluasi kegiatan dilakukan terhadap sikap peserta. Evaluasi awal tentang sikap meliputi penguasaan materi fasilitasi oleh peserta yang dilakukan sebelum dan sesudah kegiatan. Materi yang dievaluasi meliputi sikap, daya serap dan tingkat ketrampilan (aspek kognitif peserta). Materi sikap diindikasikan melalui aspek afektif peserta (dapat diindikasikan dari keseriusan dalam mengikuti pengabdian dan minat (interest) khalayak sasaran). Materi daya serap berupa pengetahuan teoritis yang diberikan dan daya serap individu secara mandiri. Materi keterampilan berupa teknik pelaksanaan kegiatan di lapangan.

Kriteria penilaian dikategorikan sebagai berikut:

$\mathrm{A}=$ amat baik (nilai evaluasi berkisar antara $80-100)$

$\mathrm{B}=$ baik (nilai evaluasi berkisar antara $70-79)$

$\mathrm{C}=$ cukup (nilai evaluasi berkisar antara 56-69)

$\mathrm{D}=$ kurang (nilai evaluasi $\leq 56$ )
Perubahan daya serap, sikap dan keterampilan sebelum dan sesudah kegiatan pengabdian dilakukan dengan matriks skala linkert (Walgito, 2003)

\section{HASIL KEGIATAN}

\section{Materi Teoritis tentang Manfaat}

\section{Tepung Biji Ketapang}

Ketapang (Terminalia catappa

L. ) merupakan tumbuhan pantai dengan daerah penyebaran yang cukup luas. (Hevira et al. 2015). T.catappa ditanam terutama untuk perlindungan daerah pantai dan pohon peneduh (Thomson \& Evans, 2006).

Biji ketapang dapat dimakan mentah atau dimasak dan dapat digunakan sebagai pengganti almond dalam pembuatan kue. Kandungan yang ada dalam biji Ketapang sebagai berikut:

Tabel 1. Kandungan Biji Ketapang (\% Berat Kering)

\begin{tabular}{llc}
\hline No. & Parameter & $\begin{array}{c}\text { Kadar Air } \\
(\%)\end{array}$ \\
\hline 1 & Kadar Air & $0,81 \%$ \\
2 & Kadar minyak & $56,66 \%$ \\
3 & Protein & $17,996 \%$ \\
4 & Gula Total & $61,5 \mathrm{mg}$ \\
5 & Vitamin C & $56 \mathrm{mg} / 100 \mathrm{gr}$ \\
& & bahan \\
\hline
\end{tabular}

Darmawan E

(20016)

mengemukakan bahwa kandungan protein dan serat yang tinggi pada biji ketapang merupakan suatu potensi yang 
dapat dimanfaatkan sebagai bahan baku ataupun bahan tambahan pada produk makanan sebagai upaya meningkat kandungan gizi dan sifat fungsionalnya. Manfaat makanan dengan kadar protein dan serat yang tinggi adalah: i) Mencukupi asupan protein; ii) Meningkatkan asupan serat yang bagus untuk metabolisme tubuh; iii) Mengurangi potensi munculnya penyakit degenerative seperti kolesterol, diabetes dan jantung

\section{Pembuatan Tepung Biji Ketapang}

Pengolahan biji Ketapang menjadi tepung relatif mudah dan tidak perlu keterampilan khusus. Uraian berikut berisikan tata cara dalam pembuatan tepung biji Ketapang.

1. Mengumpulkan buah ketapang yang sudah cukup tua

Buah yang cukup tua ditandai dengan warna kekuningan. Indikator lain adalah buah jatuh akibat dimangsa oleh pemangsa seperti tupai dan kelelawar. Kedua satwa ini biasanya memakan daging buah Ketapang, sementara biji yang terdapat di dalamnya masih utuh. Buah bekas dari kedua satwa ini dapat dipakai dengan terlebih dahulu mencucinya hingga bersih dan membuang sisa daging buah yang tersisa.

2. Mengupas dan mengeringkan biji Ketapang

Buah Ketapang yang sudah dikumpulkan dicuci dan dikupas daging buahnya yang masih menempel di kulit biji terluar. Pengupasan ini dilakukan agar daging buahnya tidak busuk dan berbelatung. Biji yang sudah dikupas dan dicuci selanjutnya di jemur di bawah sinar matahari jika musim panas. Jika musim hujan pengeringan dapat dilakukan menggunakan oven atau disangrai. Saat melakukan pengeringan menggunakan oven atau disangrai, harus diperhatikan agar biji tidak gosong karena akan mempengaruhi rasa dari tepung yang dihasilkan.

3. Memecahkan kulit biji luar

Kulit luar dari biji Ketapang terdiri dari 2 lapisan, lapisan pertama berserat dan ditutupi oleh kulit berlilin. Lapisan kedua kulit biji Ketapang berupa cangkang keras. Percepatan pemecahan kulit biji Ketapang dapat dilakukan dengan kombinasi teknik pendinginanpemanasan dan teknik mekanis menggunakan palu dan gunting 
dahan tanaman. Biji Ketapang yang sudah kering dapat didinginkan selapa 24 jam dalam Freezer, setelah didinginkan kemudian bisa dimasukkan ke dalam oven atau disangrai. Setelah melalui proses pendinginan-pemanasan, biji lebih mudah dipecahkan menggunakan palu dan dikupas pelan menggunakan gunting dahan tanaman.

4. Biji Ketapang yang sudah dikeluarkan dari kulit biji Ketapang selanjutnya dikering anginkan.

5. Biji Ketapang yang sudah dikeringanginakan selanjutnya di blender hingga butirannya menyerupai besar butiran tepung pada umumnya.

6. Selanjutnya dilakukan pengayakan agar tepung yang digunakan memiliki ukuran yang seragam. Ukuran seragam ini sangat penting untuk menghasilkan cake dengan kualitas baik.

7. Tepung yang sudah jadi selanjutnya disimpan di toples/box kecil atau plastic clif yang kedap dan kering. Tepung yang sudah masukkan dapat disimpan pada lemari atau tempat yang tidak lembab untuk menghindari terbentuknya jamur.
Proses pembuatan tepung biji Ketapang secara garis besar tertera dalam gambar berikut:

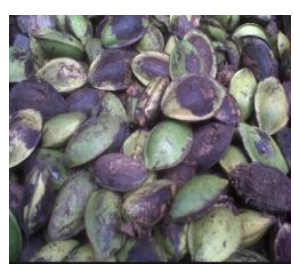

Biji Ketapang
Isi biji

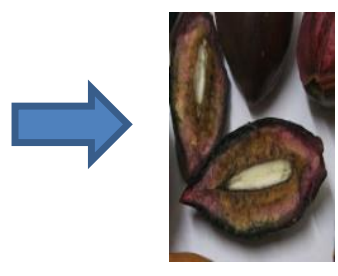

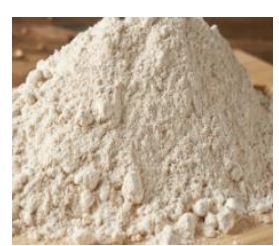

Hasil Tepung

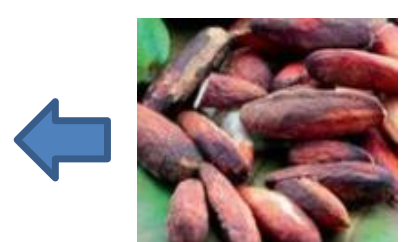

Biji

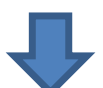

Gambar 1. Proses Pembuatan Tepung

Proporsi subtitusi tepung biji Ketapang terhadap terigu untuk olahan aneka cake

Penerapan pengolahan aneka cake berbahan tepung biji Ketapang harus tepat, agar cake yang dihasilkan berkualitas baik. Biji Ketapang tidak $100 \%$ menjadi bahan dasar pembuatan aneka cake, tetapi bersifat subtitusi. Proporsi antara tepung biji ketapang dan tepung terigu mengikuti 3 skenario perbandingan berikut:

- Skenario 1: Bahan yang digunakan 225 gr tepung biji ketapang (100\%) dan 0 gr tepung terigu $(0 \%)$. 
- Skenario 2: Bahan yang digunakan 112,5 gr tepung biji ketapang $(50 \%)$ dan 112,5 gr tepung terigu (50\%).

- Skenario 3: Bahan yang digunakan 75 gr tepung biji ketapang $(33,33 \%)$ dan 150 gr tepung terigu $(66,66 \%)$.

\section{Evaluasi Kegiatan}

Peserta penyuluhan meliputi tenaga muda bidang kehutanan dan anggota masyarakat desa yang terpilih dengan berbagai bidang pekerjaan. Evaluasi awal terdiri dari evaluasi tentang sikap dan penguasaan materi serta keterampilan dari peserta. Hasil evaluasi awal dari pelaksanaan pengabdian adalah sebagai berikut:

Tabel 1. Evaluasi tahap awal kegiatan pengabdian

\begin{tabular}{lcl}
\hline Evaluasi Kegiatan & capaian & Kategori \\
\hline $\begin{array}{l}\text { Sikap peserta yang terindikasi dari keingintahuan } \\
\text { dan minat dan keseriusan mengikuti kegiatan }\end{array}$ & $90 \%$ & A (amat baik) \\
Kemampuan peserta menguasai materi & $80 \%$ & A (Amat baik) \\
Kemampuan peserta menguasai keterampilan & $80 \%$ & A (Amat baik) \\
\hline
\end{tabular}

Evaluasi sikap peserta menunjukkan kategori amat baik $(\mathrm{A}=90 \%) \quad$ terhadap kegiatan penyuluhan. Sikap peserta tercermin dari keingintahuan di mana 8 dari 10 peserta melakukan diskusi aktif ketika penyampaian materi dilakukan. Minat peserta juga sangat besar, semua peserta yang diundang kegiatan pengabdian hadir. Tidak ada peserta yang pulang sampai acara selesai (kehadiran 100\%). Ketertarikan, minat (interest) di awal kegiatan sudah tercermin dengan ditandatanganinya persetujuan kerjasama kegiatan pengabdian antara tim pengabdi dan mitra PKK.
Kemampuan penguasan materi berada dalam kategori amat baik $(80 \%)$ dan penguasaan keterampilan juga berada dalam kategori amat baik (80\%). Suatu pencapaian positif dalam kegiatan pengabdian ketika evaluasi kegiatan menunjukkan kategori sangat baik. Capaian kegiatan juga di atas rata-rata, di mana terdapat 4 orang dari target 2 orang yang dapat menjadi fasilitator pembuatan tepung biji Ketapang sebagai bahan pengolahan aneka cake. Fasilitator dari anggota PKK ini selanjutnya yang akan menjadi penyebar pengetahuan dan keterampilan dalam pembuatan tepung biji Ketapang dan pengolahan aneka cake. 
Keterampilan dasar dalam membuat kue yang dimiliki peserta terpilih (fasilitator) menjadi faktor penguasaan keterampilan oleh peserta.

\section{KESIMPULAN DAN SARAN}

\section{Kesimpulan}

Sosialisasi intensif yang
didukung tinjauan referensi ilmiah sangat membantu tim pengabdi dalam menyebarkan pengetahuan dan keterampilan bagi mitra (anggota PKK Permata Hijau). Kegiatan pengabdian secara keseluruhan termasuk dalam kategori sangat baik yang mengindikasikan keberhasilan program pengabdian. Ketertarikan, minat (interest) terindikasi dari kehadiran peserta dan keseriusan dalam mengikuti kegiatan pengabdian. Diskusi 2 arah yang terjadi juga mengindikasikan tingginya rasa keingintahuan peserta pengabdian. Pengabdian dengan dasar teori dan praktik begitu bermanfaat bagi mitra atau tim pengabdi. Didapatkannya 4 orang anggota PKK yang menjadi fasilitator merupakan keberhasilan tersendiri. Fasilitator ini nantinya diharapkan dapat menjadi agen dalam penguasaan pengetahuan dan keterampilan dari anggota PKK lainnya. Hasil evaluasi dari kegiatan pengabdian terhadap peserta dikategorikan sangat baik

\section{Saran}

Pengetahuan dan keterampilan mitra (peserta) harus terus digali untuk mendapatkan program pengabdian yang paling cocok dan dapat diaplikasikan. Menciptakan suasana komunikasi interaktif melalui teknik diskusi 2 arah menggunakan kombinasi bahasa formal dan formal penting dilakukan dalam kegiatan sosialisasi dan bimbingan keterampilan. Penguasaan pengetahuan dan keterampilan dari tim pengabdi yang diimbangi oleh tingkat keterampilan mitra menjadi faktor penting yang menentukan keberhasilan program pengabdian. Pembentukan fasilitator menjadi media penting yang dapat menjadi agen perubahan ke arah yang lebih baik dalam kegiatan pemberdayaan masyarakat.

\section{DAFTAR PUSTAKA}

Darmawan E. 2016. Pemanfaatan Biji Ketapang (Terminalia catappa) Sebagai Sumber Protein Dan Serat Pada Produk Makanan Stik. Agrotech, Vol 1, No. 1 Mei 2016.

https://ejournal.widyamataram.a c.id/index.php/agrotech/article/ view $/ 5 / 3$

Hevira L., Munaf E., Zein R. 2015. The use of Terminalia catappa $L$. fruit shell as biosorbent for the 
removal ofPb(II), $\mathrm{Cd}(\mathrm{II})$ and $\mathrm{Cu}(\mathrm{II})$ ion in liquid waste. Journal of Chemical and Pharmaceutical Research, 7(10):79-89. https://scholar.google.co.id/ $\underline{\text { scholar?oi=bibs\&cluster }=51309}$ $\underline{21660338948450 \& b t n I=1 \& h l=\mathrm{i}}$ d

Muanmar., Suleman, S.M., Nurdin, M. (2017). Jenis - jenis Tumbuhan di Pesisir Pantai Desa Tibo dan Pemanfaatannya sebagai media pembelajaran. e-JIP BIOL Vol. 5 No. 1. http://jurnal.untad.ac.id/jurnal/i ndex.php/EBiol/article/view/93 $\underline{59 / 7435}$

Ndraha, T. 2005. Teori Budaya Organisasi. PT. Rineka Cipta. Jakarta

Patricia, V. et al. 2016. Uji Efektifitas Ekstrak Daun Ketapang (Terminalia catappa) Terhadap Bakteri Bacillus amyloliquefaciens. Jurnal Ilmiah Farmasi.
Vol.5.No.1.ISSN 2302- 2493. https://ejurnal.its.ac.id/index.ph p/sains_seni/article/ download/3593/1404

Riskitavani DV dan Purwani KI. 2013. Studi Potensi Bioherbisida Ekstrak Daun Ketapang (Terminalia catappa) terhadap Gulma Rumput Teki (Cyperus rotundus). Jurnal Sains dan Seni Pomits Vol. 2, No.2, (2013) 2337-3520 (2301-928X Print). http://ejurnal.its.ac.id/index.php /sains_seni/article/view/3593

Thomson, Lex \& Evans, Barry. 2006. Terminalia catappa (Tropical Almond). Species Profiles for Pacific Island Agroforestry. https://www.researchgate.net/pu blication/ 228374099_Terminalia_catappa _Tropical_Almond/citation/dow nload

Walgito B. 2003. Psikologi sosial (Suatu Pengantar), Edisi Revisi. Penerbit Andi. Yogyakarta. 